\title{
I. V. Arnold's Theory of Foregrounding and Its Application to Text Analysis
}

\author{
VERA MENIAILO
}

\begin{abstract}
The theory of foregrounding, developed by St. Petersburg scholar Irina Vladimirovna Arnold in the middle of the 20th century, was rather revolutionary for its time as it aimed to establish connection between formal levels of the language and textual meanings that allowed the reader to decode the author's message. Arnold identifies four principal elements of foregrounding that disclose conceptual textual meaning: the strong position of a text, repetitions on different levels of language, the convergence of stylistic devices and defeated expectancy. The professor states that these elements of the text are always intentional and, thus, give a key to understanding the author's message and position. This theory, being universal and easy to apply, has been widely used by Russian scholars working in the domain of textual linguistics and stylistics until nowadays. Such an approach increases the objectivity of the scientific findings in this area and enriches the overall text analysis with extra details and more meanings disclosed. The paper gives an overview of the theory of foregrounding, emphasizing the role it plays in text analysis and stylistics of decoding, and illustrates its principles with examples of practical analysis of the text conducted by the author of the paper.
\end{abstract}

Keywords: foregrounding; decoding; stylistics of decoding; I. V. Arnold

\section{Introduction}

The anthropocentric nature of the contemporary linguistic paradigm influences the focus and approaches to language analysis in such a way that allows seeing a human mind behind the language and adding to its comprehension. This is even truer when it comes to text analysis because a text, especially a literary one, has always been perceived as a product of a human's mental and creative activity. Even at the time when formal approaches to text analysis dominated, the figure of the creator of the literary text could not be totally neglected. What with the current human-focused linguistics, it becomes absolutely crucial in the process of text analysis to come as close 
as possible to decoding the meaning the author of the text intended to share with the reader. In the middle of the $20^{\text {th }}$ century, St. Petersburg scholar, Irina Vladimirovna Arnold, suggested an innovative approach of applying the theory of foregrounding to text analysis, which aimed to establish a connection between the formal levels of the language and textual meanings that allowed the reader to decode the author's message. That approach was revolutionary for its time, however, it perfectly matches the aims and principles of contemporary textual linguistics and is widely applied by Russian linguists.

The paper will outline the origins of the term "foregrounding", give a brief overview of theories and conceptions that influenced Arnold's theory and concentrate on its key theses. Then, a practical analysis conducted by the author of the article will try to demonstrate the applicability of the principles proposed by Arnold to text analysis. Novels of the English writer of the $20^{\text {th }}$ century, John Fowles, were chosen as an illustrative material as they combine both realist, psychological and postmodernist literary traditions and, thus, can prove the universal nature of the developed theory of foregrounding and its potential when studying texts of various genres.

\section{Development of the Theory of Foregrounding and Its Interpretation by I. V. Arnold}

The term "foregrounding" is actually the English rendering of the Czech word "aktualisace" (Cuddon 2013: 284), which was first introduced by the Czech linguist Jan Mukařovský (Mukařovský 1964), a member of the Prague linguistic circle. He distinguished between standard and poetic languages, claiming that poetic language is not simply a variant of the standard one. However, he stated that standard language fulfilled the function of a ground for poetic language, which placed "in the foreground the act of expression" (ibid.). That act of expression or foregrounding is achieved by a deliberate breach of a standard language norm. This is how the term "foregrounding" is generally interpreted by contemporary scholars: as "giving unusual prominence to one element or property of a text, relative to other less noticeable aspects" (Baldick 2008: 133) or "the use of devices and techniques which 'push' the act of expression into the foreground so that language draws attention to itself" (Cuddon 2013: 284).

The first attempts to describe principles of foregrounding can be found in the theories of Russian formalists, especially in the works of V. B. Shklovsky. He used the concept of "defamiliarization" ("otstranenie") to stress the special nature of literary works that draw attention to how they say something rather 
MENIAILO

than what they say in order to create an image and attract the reader's attention to it (Shklovsky 1919). Later various means of foregrounding were described with different degree of specification in the works of V. V. Vinogradov (1947), L. T. Milic (1967), R. Jakobson (1986), S. R. Levin (1962), L. Doležel (1971), M. Riffaterre (1964) and others. In her "Stylistics of Decoding" (1990) Arnold systematized types of foregrounding, described earlier in isolation by different scholars, but, what is more important, she gave new interpretation of the term "foregrounding" and filled its application to the practical stylistic analysis with new sense. She disagrees with formalists and structuralists who claimed that foregrounding was switching attention from the content to the form. Arnold believes that foregrounding highlights the most significant shades of meaning and by drawing the reader's attention to certain parts of the text helps him to notice connections between ideas and importance of particular images and events for the interpretation of the whole text (Arnold 2016: 195).

Arnold enriches the findings of her predecessors by applying theory of information and computer sciences apparatus to text analysis. In her 1972 and 1974 articles about possibilities of using a term "quantization" in stylistics (see: Arnold 2016: 132-148, 183-193) she convincingly describes a text as a codified system of signals and claims that theory of information is "heuristically useful" for the text studies even when the quantitative analysis is not applied (ibid. 145). The author chooses, compresses and codifies information, characters, ideas, feelings and one's attitude towards reality by means of language in a form of a text and in this textual form they approach the addressee (the reader). For the reader this text must again become a set of ideas, feelings, characters etc., for which it must be decoded. This is what stylistics of decoding does (ibid. 129). Nevertheless, even when applying principles of computer analysis to a text Arnold never falls into formalism and even claims that stylistics of decoding can be called pragmatic stylistics, because it is interested not in the text with its figures and images, but in its impact on the reader (ibid. 178). It is difficult to argue with such scholar's interpretation of her theory and, besides, it is worth noting that principles of stylistics of decoding were described in the 1960s, while foundational works that laid basics of pragmatics were published by J. Searle and H. Grice in 1970s and the beginning of 1980s.

The literary studies tradition usually distinguishes between the so-called "stylistics of the author" and "stylistics of the reader". Stylistic analysis "from the author" has a literary studies nature, while analysis "from the position of the reader" has linguistic focus (ibid. 128). The difference between these two stylistics lies in the fact that stylistics "from the author" is interested in the reasons and circumstances that led the author to creation of the work of art, as 
a result, the text is viewed as a consequence of certain events in the author's life. Stylistics of decoding treats the text not as a result but as a reason and a source of impressions for the reader (Arnold 1990: 28). To apply the first approach to text analysis, one needs to possess a broad knowledge not only of the author's life but also about political, social and cultural trends of his time. Moreover, Wellek and Warren argue that one should carefully apply historic data about the author's intentions to interpreting the text. Even when a researcher possesses evidence of the author's contemporaries or the author himself, which clarify the author's intentions, one should definitely take such data into consideration with certain care. It is necessary to evaluate it critically in the respect of what can be derived from the text itself (Wellek, Warren 1962). Still, these two approaches do not exclude each other and should be used together.

Ideally, a researcher interested in a thorough interpretation of a literary work should first study the text itself, applying the principles of foregrounding, and then study biographic data about the author. Such a sequence of two methods application seems logical as it enables the interpreter to avoid a biased view, which is inevitable in case he starts with a biographical study, because he might fall into trying to search proves to some facts of the author's life in the text instead of treating the text from a naïve reader's position. Besides, such an order of the steps of analysis resembles the natural way a typical reader approaches the text. Seldom a person starts reading a book by studying the author's bio note or critical analysis of the novel, often this comes as a second step if the reader gets interested in the book and wants to check one's understanding of it.

There are two main means of foregrounding realization: strong positions of the text and schemes of textual organization. Strong positions of the text are beginning (including title, epigraph, prologue and first paragraph of the text) and ending of the text or a part of the text. As for schemes of textual organization, Arnold concentrates on the convergence of stylistic devices, key words repetition, defeated expectancy and coupling (term of S. Levin) or parallelism (term of R. Jakobson) (Arnold 2016: 222). It is necessary to stress that key textual meanings are usually foregrounded on different levels of the text and through a combination of means of foregrounding. The application of the principles of foregrounding to interpretation of the text instead of mere analysis of stylistic devices leads to more justified conclusions as all the types of foregrounding cover either the whole text or its considerable parts (ibid. 224). Arnold's theory stands on the ground that all elements of the text, even their order in the text, are intentional and can give a clue to understanding of the author's message. 
MENIAILO

Application of the Theory of Foregrounding to Text Analysis

The following part of the article demonstrates how the above-mentioned principles of foregrounding help to interpret the text and identify the author's message. The article does not aim to present a systematic analysis of the chosen novels (although such an analysis was conducted by the author in her $\mathrm{PhD}$ thesis and proved to be successful), only to illustrate application of the studied theory to practical material. That is why, the examples of the analysis are organized by means of foregrounding, not by texts.

Key words + Strong position (The Collector by J. Fowles). On the thematic level of the novel the opposition of the collector Clegg to the artist Miranda is a symbolic opposition of the world of trade and collection to the world of art. Similar to Clegg, who literally kills Miranda by captivating her and hiding from the outer world, a collector, who buys and hides pieces of art from other people, makes an object of art lifeless to a certain extent. Besides the title, the lexeme and its derivatives are repeated throughout the text: "to collect" (11), "collection" (8), "collector" (6), "collecting" (7). Names of different butterflies ("Burnet cocoons", "Pale Clouded Yellow"), which Clegg has in his collection, together with the words describing the process of arranging them in the collection ("observations diary", "catching a rarity", "looked after my collection") also appear in the strong position of the text (the first paragraph of the novel) (Fowles 1964: 7), thus, foregrounding, the author's message. The fact that this information breaks into Clegg's reminiscences about Miranda confirms such an interpretation of the novel, moreover, it hints at the novel's tragic ending.

Defeated expectancy + Strong position (The French Lieutenant's Woman by J. Fowles). The French Lieutenant's Woman is centered around an existential quest of the protagonist, Charles Smithson. He is struggling to make a choice of his life between marrying wealthy Ernestina Freeman and following his love to a poor outcast Sarah Woodruff. For Charles making the right choice equals to finding his true place in the life. In the bildungsroman tradition, which Fowles formally follows in this novel, the title of the novel usually names its main character (compare with Oliver Twist, David Copperfield, Jane Eyre, Emma, Tess of the D'Urbervilles etc.). The reader accustomed with this tradition logically expects Sarah, who is known under the nickname 'The French Lieutenant's Woman' among the local citizens, to be the protagonist. This expectation is supported by the epigraph to the first chapter. A poem "The Riddle" by 
T. Hardy seems to describe Sarah and her way of living. The chapter finishes with the description of Sarah. Only after several chapters the reader starts to guess that it is Charles and his personal development that are in the focus of the author's attention, not Sarah, who is, in fact, a static character that only helps Charles to undergo his personal transformation. Such a play with one's reader conforms to the principles of postmodernist aesthetic. However, Fowles does not simply follow the rules of postmodernist writing, but tries to warn the reader against fast and perfunctory interpretations of his text.

The principle of defeated expectancy is widely used throughout the whole novel. On the lexical level, appearance of unexpected elements signals the reader that the text should not be treated like a traditional Victorian novel. Fowles often introduces metaphors and comparisons that contain words naming $20^{\text {th }}$-century realia: "Charles [...] was like a city struck out of a quiet sky by an atom bomb" (Fowles 1996: 151) or "...she [Sarah] was born with a computer in her heart" (ibid. 22). By doing this, the author distances himself from the narration and invites the reader to do the same and to evaluate the actions of the characters not from the position of Victorian morals but from the point of view of the person acquainted with the findings of psychology in the 20th century. Such a perspective is necessary for the reader to correctly interpret the famous two variants ending of the novel and, thus, to disclose the author's existential message.

\section{Convergence of stylistic devices (The French Lieutenant's Woman by}

J. Fowles). Sarah teaches Charles to fight for his freedom and to bear the responsibility for one's free choice. Under her influence Charles' desire for freedom grows, transforming him from a conventional Victorian gentleman to an existentialist in the contemporary understanding of this concept. The convergence of stylistic devices in the following context enables the author to demonstrate Charles' emotional naivety and highlight Sarah's role of a mentor: “But her [Sarah's] arms came round him and pressed his head closer. He did not move. He felt borne on wings of fire, hurtling, but in such tender air, like a_child at last let free from school, a prisoner in a green field, a hawk rising" (ibid. 150). The meaning is foregrounded through the use of gradation ("a_child let free from school" - "a prisoner in a green field" - "a hawk rising"), metaphors ("felt borne on wings of fire" and "hawk rising") and comparison ("he felt like a...").

1 Hereinafter boldface font is introduced by the author, V.M. 
MENIAILO

Convergence of stylistic devices (The Magus by J. Fowles). The protagonist Nicholas Urfe, who is an ambitious egocentric young man at the beginning of the novel, splits up with loving and devoted Alison Kelly and moves to a Greek island Phraxos. There he falls under the influence of mysterious Maurice Conchis, "the magus", who gives him a serious of existential and sometimes quite cruel lessons that make Nicholas reconsider his individualistic approach to life and people around him. Nicholas realizes that his main problem was inability to act freely and consciously instead of constantly playing a role to confirm to the image of himself that he had created in his mind. This idea is foregrounded in the following context through a convergence of stylistic devices: “... all my life I had tried to turn life into fiction, to hold reality away; always I had acted as if a third person was watching and listening and giving me marks for good or bad behavior - a god like a novelist, to whom I turned, like a character with the power to please, the sensitivity to feel slighted, the ability to adapt himself to whatever he believed the novelistgod wanted. This leechlike variation of the supergo I had created myself, fostered myself, and because of it I had always been incapable of acting freely. It was not my defense; but my despot." (Fowles 1979: 549) There is an inversion (“always I had acted”), polysyndeton ("watching and listening and giving"), comparison together with parallelism ("a god like a novelist, I... like a character"), author's neologism ("novelistgod") and parallel structures ("the power to please, the sensitivity to feel, the ability to adapt”), pointing at Nicholas' readiness to change his behaviour ("giving me marks for good or bad behavior"). In addition, the importance of the ability to make the right and free choice is emphasized through the repetition of the lexemes "choice" (30) and "to choose" (35) in the text of the novel.

Repetition of key words (Daniel Martin by J. Fowles). Daniel Martin is in many respects an autobiographical novel, which tells about the life of a writer and scriptwriter for about forty years. The description of the events of the life of an adult Daniel is mixed with flashbacks to his childhood and youth. The constantly changing time of narration together with the rich for events plot reflect Daniel's attempts to find his true place in the life. The setting of the novel is dynamic as Daniel moves from England to the USA and back, takes a trip along the Nile and visits his family farm in Devonshire. Gradually Daniel realizes that it is only on this solitary farm (Thorncombe) that he feels comfortable, free from the influence of the outer world and, finally, in harmony with himself. This idea is foregrounded by the repetition of the lexemes naming this place (Thorncombe -80 and Devon - 31) in combination with the words 
"retreat", "secret" (place/island), "peace", "solitude", which contain the semes "withdrawing”, "unknown”, "unseen”, "single”, “calm”, "not disturbed”. All the mentioned lexical components are associated with the concept of an asylum where one can find solitude and peace. See the examples:

1) I too was tired of London, for over a year I had been traveling. I began to feel the need of somewhere to retreat, to rest up... (Fowles 1998: 146)

2) There was a sense in which it was a secret place, a literal retreat. (Ibid. 364)

3) As if Thorncombe were some secret island, non-existent without him, unknown to anyone but him. (Ibid. 392)

4) As always, Thorncombe had already made him retreat into the past, his lost domain, his other world, and it had not needed her voice to remind him of the new distance between them; almost the distance of the imagined from the real. (Ibid. 470)

5) He would stick to his original plan: Kitchener, then retreat, Thorncombe, peace; a long green spring and summer. (Ibid. 508)

6) ...overwhelming longing for the peace and solitude of Thorncombe. Retreat, to lick wounds, to discover what had gone wrong, not only with Daniel Martin, but his generation, age, century... (Ibid. 643)

\section{Conclusion}

To conclude, Arnold's contribution to the development of textual linguistics and literary studies, overall, was obviously significant for her time and continues to be of practical importance for contemporary linguists. Following the tradition of textual analysis established by Russian formalists and Czech structuralists, she developed an objective and easily verified algorithm of text analysis, enriching it by the current findings of computer studies and theory of information. In addition, having given credit to Russian and foreign specialists in stylistics, she systematized fragmentary and often intersecting classifications of stylistic devices within her "stylistics of decoding". However, her primary aim was not to simply improve the methodology of description of formal levels of a text but to objectively interpret the meaning of a literary work. That approach was quite new for the literary studies of the 1960-70s, but is within the present day anthropocentric linguistic paradigm. Again, Arnold's conception is of vital importance for contemporary textual studies as is prevents a researcher from getting lost in possible interpretations of 
MENIAILO

complicated postmodernist and various neo- genres texts. The practical analysis, demonstrated in this paper, proves the fruitfulness of application of Arnold's theory of foregrounding to literary text analysis.

\author{
Vera Meniailo \\ menyaylo917@mail.ru \\ National Research University Higher School of Economics \\ Sojuza Pechatnikov 16 \\ 190121 St. Petersburg \\ RUSSIA
}

\title{
References
}

Arnold, I. V. 1990. Stilistika sovremennogo anglijskogo jazyka (stilistika dekodirovanija). M.: Prosveshchenije. (АрнольА, И. В. 1990. Стилистика современного английского языка (стилистика Аекодирования). М.: Просвещение)

Arnold, I. V. 2016. Semantika. Stilistika. Intertekstualnost. Izd. 4. M.: Lenand. (ApнольА, И.В. 2016. Семантика. Стилистика. Интертекстуальность. ИзА. 4. М.: Аенана.)

Baldick, C. 2008. The Oxford Dictionary of Literary Terms. Oxford: Oxford University Press.

Cuddon, J. A. 2013. The Penguin Dictionary of Literary Terms and Literary Theory. London: Penguin Reference Library.

Doležel, L. A. 1971. Toward a Structural Theory of Content in Prose Fiction. - Literary Style: A Symposium. London; N.Y.: Oxford University Press, 95-110.

Fowles, J. 1964. The Collector. N.Y.: Dell Publishing.

Fowles, J. 1979. The Magus. N.Y.: Dell Publishing.

Fowles, J. 1996. The French Lieutenant's Woman. London: Vintage.

Fowles, J. 1998. Daniel Martin. London: Vintage.

Jakobson, R. 1986. Raboty po poetike. M.: Progress. (Якобсон, Р. 1986. Работы по поэтике. М.: Прогресс.)

Levin, S. R. 1962. Linguistics Structures in Poetry. 's-Gravenhage: Mouton.

Milic, L. T. 1967. Style and Stylistics. An Analytical Bibliography. N.Y.: Free Press.

Mukařovský, J. 1964. Standard language and poetic language. - P. L. Garvin, ed. \& trans., A Prague School Reader on Esthetics, Literary Structure, and Style. Washington, D.C.: Georgetown University Press, 17-30.

Riffaterre, M. 1964. The Stylistic Function. - Proceedings of the Ninth International Congress of Linguists. The Hague: Mouton, 316-322.

Shklovsky, V. B. 1919. Iskusstvo kak priem. - Poetika. Petrograd: 18 Gos. Tipografia, 13-26. (Шкиовский, В.Б. 1919. Искусство как прием. - Поэтика. ПетрограА: 18 Гос. типография, 13-26) 
I. V. Arnold's Theory of Foregrounding and Its Application to Text Analysis

Vinogradov, V. V. 1947. Russkij jazyk. Grammaticheskoje uchenije o slove. M.-L.: Uchpedgiz. (Виноградов, В.В. 1947. Русский язык. Грамматическое учение о слове. М.-А.: УчпеАгиз)

Wellek, R., Warren, A. 1962. Theory of Literature. N.Y.: Harcourt, Brace \& World. 